\title{
The Artificial Lighting Analysis of Study Rooms in Dormitories and Classrooms Islamic Boarding School of Lil Banat Parepare
}

\author{
Ni'mah Natsira,*, Nurul Jamala ${ }^{\mathrm{b}}$, Asniawaty Kusno ${ }^{\mathrm{c}}$ \\ aDepartment of Architecture, Faculty of Engineering, Hasanuddin University, Makassar. Indonesia. Email: nimahna15@ gmail.com \\ bDepartment of Architecture, Faculty of Engineering, Hasanuddin University, Makassar, Indonesia. Email: nuruljalama@yahoo.com \\ 'Department of Architecture, Faculty of Engineering, Hasanuddin University, Makassar, Indonesia. Email: kusno_asniawaty@yahoo.com
}

\begin{abstract}
This study aims to determine the light intensity in the study room of the DDI Lil Banat Islamic boarding school in Parepare. Measurements were taken in classrooms and dormitories. The type of research used is quantitative with the simulation method. The dependent variable with the measurement of exposure is light intensity. While the independent variables are the arrangement of lighting points and the layout of the study room. Measurements were carried out for three days using a digital lux meter. The measurement results show that the light intensity in the dormitory has not met the Indonesian National Standard for study rooms both day and night. During the day the classroom meets the Indonesian National Standard but not at night. Although students as room users feel comfortable with the light intensity conditions in the study room and can study according to these conditions, students still feel some complaints in the form of sore eyes, eye strain and difficulty focusing. Therefore, researchers make recommendations for study room designs that can make students more comfortable studying in dormitories and classrooms so that they can reduce complaints while studying. Lighting design recommendations are made in several alternatives by increasing the number of lamps and changing lamp types using Dialux simulation. The simulation results of the study room lighting design recommendations have met the usage standards so that they can be applied to dormitories and classes at the DDI Lil Banat Islamic Boarding School in Parepare.
\end{abstract}

Keywords: Artificial lighting design; light intensity; study room

\section{Introduction}

Lighting has a very important role in architecture, both in supporting the function of space and the activities of the space, create aesthetic visual images, and creating comfort and security for space users [1]. In planning a building, lighting design is a very important thing to note, because the activities of space users affect the distribution of light in space. Light distribution not only serves to make a visual object clearly visible, but also serves to evoke visual comfort that psychically affects the resilience of space users in maintaining their performance [2]. Basically in designing space lighting, an architect will refer to the standard recommendations of illumination [3].

Lighting that is too bright will make the space user feel awake and very active. While the dim lighting creates a sense of relaxation may even be sleepy. This is a psychological effect in the physical form of lighting. The atmosphere of space can be created from the color and intensity of its light [4].

In the learning process that requires thoroughness in the

\footnotetext{
*Corresponding author. Tel.: +62812 45064415

Pemuda Street No.16, Makassar, Sulawesi Selatan Indonesia
}

absence of adequate lighting, the impact will be very pronounced on eye fatigue, the occurrence of eye muscle fatigue and eye nerve fatigue as a result of continuous stress on the eyes, although it does not cause damage to the eyes permanently, but the impact can increase workload, accelerate fatigue, loss of work time, interfere with concentration and decrease work productivity.

Learning is an activity that in the process supports high concentration. A comfortable place and learning environment make it easy for students to concentrate. By preparing the right environment, students will get better results and can enjoy the learning process carried out [5]. The Islamic boarding school environment, both schools, dormitories and mosques, must be designed as well as possible to facilitate students in the implementation of teaching and learning.

The current trend of building schools that implement a residential or boarding system, Islamic boarding school or tahfidz schools that require comfortable facilities, especially classes and dormitories as places for various activities, guiding the role of researchers to examine classrooms and dormitories in terms of lighting in order to maximize the function of space as a place to rest at once a place to learn. 
Islamic boarding school of DDI Lil Banat is one of the boarding school in the city of Parepare which has a dormitory. After conducting initial research through interviews of several students and measuring the lighting in the dormitory, the results indicated that there was discomfort in the learning activities of the students in the dormitory due to the unfavorable conditions of the hostel. Some things that result in less conducive conditions include poor lighting and ventilation. This is evidenced by making initial measurements using the Light Meter application, the average lighting in the dormitory is $168 \mathrm{~lx}$. One example of a dormitory with only 2 lights in a room measuring $8.5 \mathrm{~m} \mathrm{x}$ $7.5 \mathrm{~m}$.

Based on this, the researcher intends to conduct research on the lighting of the study room, in this case, the class and dormitory at the Islamic Boarding School of DDI Lil Banat to find out whether the dormitory lighting system meets the Indonesian National Standard (SNI) and whether the effect of learning room lighting on students' learning activities. This research is expected to contribute to future researchers who will raise a similar theme and can be input for the parties involved in this research.

\section{Literature Review}

\subsection{Lighting}

Lighting is one of the factors to get a safe and comfortable environment and is closely related to human productivity. Good lighting allows people to see the objects they are working on clearly and quickly. Good lighting affects the quantity and quality of vision. Adequate lighting gives the impression of better scenery and refreshing environmental conditions [6]. Inadequate lighting creates additional physical or psychological burdens for space users. This can cause eye fatigue with symptoms such as decreased eye acuity, double/blurred vision, pain around the eyes and errors in work or work accidents [7]. According to the source, lighting can be divided into:

\section{a. Natural Lighting}

Natural lighting is a source of lighting that comes from sunlight. Natural rays have many advantages, besides saving electrical energy, they can also kill germs. To get natural lighting in a room, large windows or glass walls are required at least $1 / 6$ of the floor area.

\section{b. Artificial Lighting}

Artificial lighting is lighting produced by light sources other than natural light. Artificial lighting is needed when the position of the room is difficult to reach by natural lighting or when natural lighting is insufficient. Artificial lighting or also known as artificial lighting is the secondlargest energy consumer after air conditioning [8]. Electrical lighting in a building must be able to create ambient, accent space and objects, support the performance of certain work according to the function of space and expose decorative features [9]. The standard lighting level for educational institutions issued by SNI03-6575-2001 is $250 \mathrm{~lx}$ for classrooms, 120-250 lx for bedrooms, $300 \mathrm{~lx}$ for libraries, $350 \mathrm{~lx}$ for computer and workrooms, $500 \mathrm{~lx}$ for laboratories, and $750 \mathrm{~lx}$ for drawing space (using additional local lighting on the drawing table).

\section{c. The Effect of Lighting on the Study Room}

Light is an important element for seeing, therefore the amount of light received by the eye must be sufficient, neither less nor excess. Excess or lack of light can affect a person psychologically and physiologically. Poor quality of classroom lighting can cause drowsiness, lack of enthusiasm, and difficulty focusing on subjects [10]. In some conditions, it was found that the study room was not in accordance with the lighting standard, but the room users still felt comfortable in learning. Several studies on lighting show that the lighting design of the library reading room is not in accordance with the illumination standard recommended by SNI 03-6575-2001, namely 250 1x, but visitors can still do their activities properly [11].

\subsection{Study room}

In receiving and digesting lessons students need an environment atmosphere and conducive learning conditions. The atmosphere of the learning environment is neatly organized so that it supports students to receive and digest the subject matter taught by the teacher. Conducive learning room conditions must meet the criteria: good lighting, fresh air exchange, blinding wall coloring, good and neat condition of facilities and infrastructure, cleanliness of the study room [12].

\section{a. Classroom}

The classroom as a study room is a room that is bounded by walls, or bulkheads, and used as a place to learn to teach. There are several principles that need to be considered by teachers in organizing the physical environment of the class, namely: Visibility ( Flexibility of Views), Accessibility (easy to achieve), Flexibility (Flexibility), comfort and beauty [13].

\section{b. Dormitory}

Dormitory is a type of housing that is permanent and has distinctive characters. Usually, a dormitory is always in contact with educational institutions. The activities in the dormitories are learning, sleeping and socializing.

\subsection{Islamic boarding school}

Pondok pesantren is a series of words consisting of pondok and pesantren. The word Pondok (room, hut, small house) is used in Indonesian, emphasizing its simplicity. Pondok comes from Arabic funduuq (فندوق) which means inn. a simple dormitory or guesthouse, because the cottage is indeed a simple shelter for students/santri who are far from their place of origin [14]. In terminology, Islamic boarding school is an Islamic education institution with a 
boarding or boarding system where the chaplain is the central figure, the mosque is the center of the activity that animates it, and the teaching of Islam under the guidance of chaplain is followed by students as its main activity [15].

\section{Research Methods}

\subsection{Research sites}

The research are located in one of the cities in South Sulawesi shown in Figs. 1, namely the city of Parepare, which has an area of $99.33 \mathrm{~km}^{2}$ and a population of \pm 140,000 people. The city of Parepare is located on a bay overlooking the Makassar Strait. In the north it is bordered by Pinrang Regency, in the east, it is bordered by Sidenreng Rappang Regency and in the south, it is bordered by Barru Regency [16].

The research location is in Soreang District, precisely in Ujung Lare Village, Abubakar Lambogo street Number 53 shown in Fig. 2. Islamic boarding school of DDI Lil Banat Kota Parepare has a land area of $35,000 \mathrm{~m}^{2}$ and a building area of $6,000 \mathrm{~m}^{2}$. The status of the building itself belongs to the foundation consisting of school buildings, offices, halls, libraries, laboratories, dormitories, teacher housing, canteen, mosque and poskestren (pos boarding school health) [17].

\subsection{Types of research}

The used in this research is quantitative, using simulation methods. This research also uses the Positivism paradigm, the existing reality will be studied to test the hypothesis so that the results will be certain. This type of research is based on data collected during the study which is analyzed and then described or described based on standards or theories and related literature.

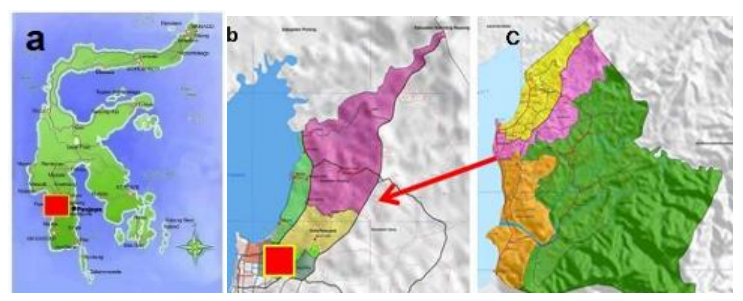

Figure 1. (a) Map of Sulawesi (b) Map of Soreang District (c) Map of Parepare City

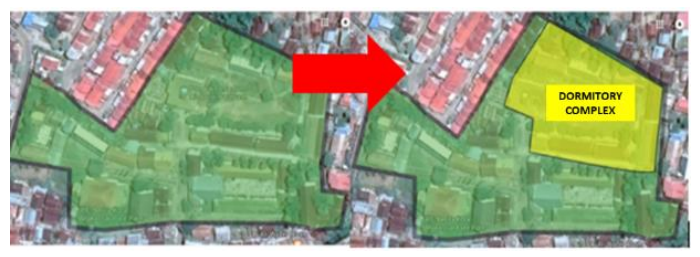

Figure 2. Map of research locations, dormitory complex

\section{a. Population and sampling techniques}

The population in this study were all classes and dormitories with simple conditions used by the students while in the boarding school area. The sampling technique in this determination uses a non-probability sampling technique. For sampling using a purposive sampling method. The samples were chosen were dormitory Fatimah 1, Aisyah 1, Khadijah 2, Aminah 1, Hafsah 1, Maemunah 1 , class XI IPS and VIII B.

\section{b. Data collection technique}

To have this research more focused, and based on the problem formulation that has been described, the data collection techniques used namely: observation, study of literature, documentation, measurement of light intensity in the study room, questionnaires and simulation.

\subsection{Data analysis technique}

This research is a quantitative analysis with descriptive statistics. The descriptive static analysis technique used in this research is the presentation of data in a visual form such as histograms, polygons, bar charts, pie charts and pastel diagrams (pie charts).

\section{Discussion}

4.1. Measurement results of the intensity of tubes lighting classrooms in Islamic Boarding School of DDI Lil Banat

Measurement of light intensity is divided into 8 classrooms are boarding Fatimah 1, dorm Aisyah 1, dorm Khadijah 2, dorm Aminah 1, dorm Hafsah 1, dorm Maemunah 1, classroom XI and clasroom VIII B.

Measurements using the Lux Meter are carried out in 4 times to represent the time of morning, afternoon, evening and night for 3 consecutive days, namely 15-17 September 2019. Morning $09.00-11.00$ GMT +8 , noon $12.00-14.00$ GMT +8 , afternoon 16.00-18.00 GMT +8 and night at 20.00-22.00 GMT +8. The following are the results of measuring the intensity of lighting in the learning room Islamic boarding school of the DDI Lil Banat Parepare

\section{a. Fatimah 1 Dormitory}

Fatimah 1 has a room size of 8 meters long and 7 meters wide inhabited by 20 students, has front (north) and rear (south) ventilation so that cross ventilation can occur in the room this, while there are only 2 lamps. This room has 12 measuring points, consisting of measuring points near the opening and under the lamp. Measuring points that are close to the openings towards the north are points A3, B3, C3 and D3, measuring points that are close to the south opening, namely points $\mathrm{A} 1, \mathrm{~B} 1, \mathrm{C} 1$ and $\mathrm{D} 1$, while the measuring points that are close to the lights are point $\mathrm{A} 2$, B2, C2 and D2. 


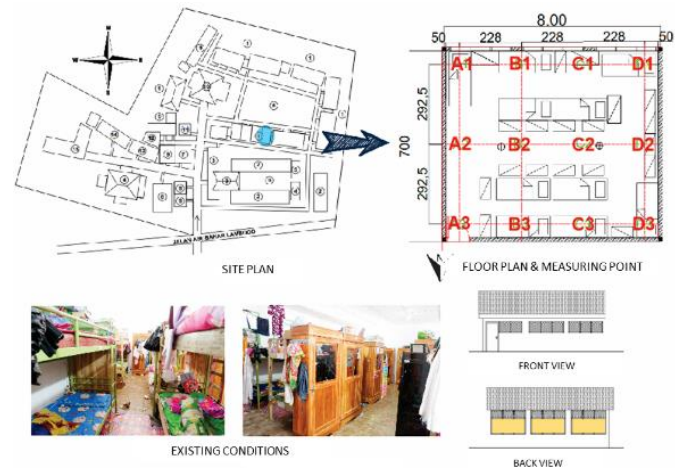

Figure 3. General overview of Fatimah 1 dormitory

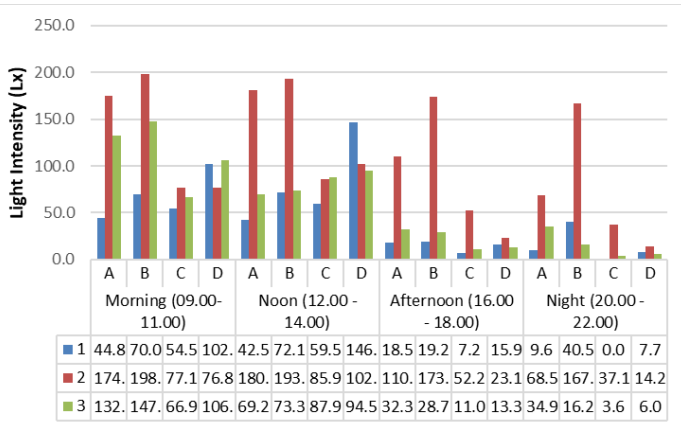

Figure 4. Measurement results of Fatimah 1 dormitory

The results of measuring the light intensity of the Fatimah 1 dormitory for 3 days at 4 different times from $09.00-22.00$ GMT +8 can be seen in Fig. 4 of the measurement results of the Fatimah 1.

The highest light intensity at point B2 is good in the morning, day, evening, or night, this is because point B2 is close to the lights, so the intensity is higher than the other points. While the lowest point is point $\mathrm{C} 1$ because the point is far from lights and openings so that it gets less light from both lights and sunlight from outside the room.

The results of the above measurements then made the average light intensity at Fatimah's dormitory for 3 days at 4 different times.

The highest average measurement result at point 2 (which is in the middle of the room) during the day is 140.4 lx when compared to the Indonesian national standard, namely $250 \mathrm{~lx}$, it is concluded that the lighting of Fatimah 1 dormitory for the study room has not met standard.

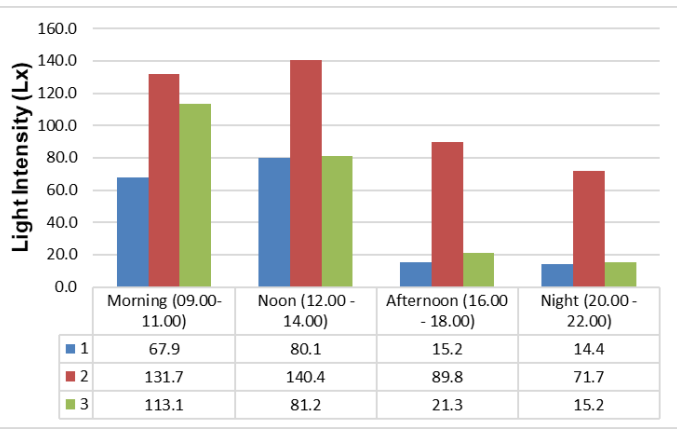

Figure 5. Average measurement of Fatimah 1 dormitory

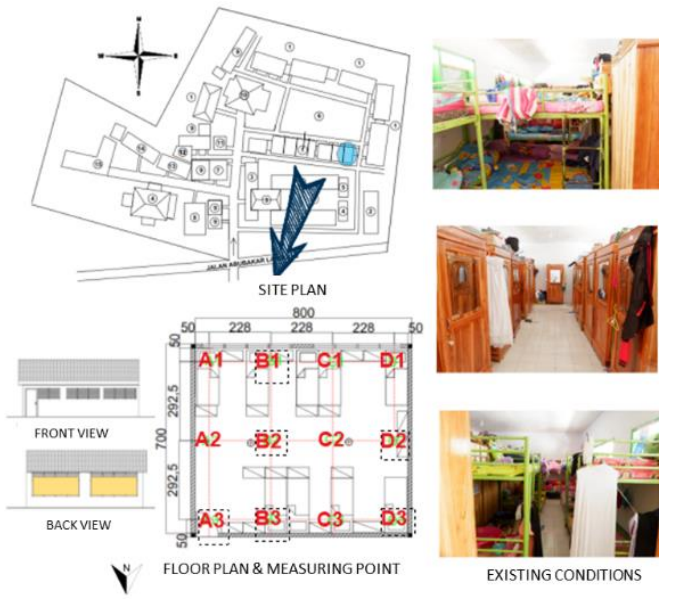

Figure 6. General overview of Aisyah 1 dormitory

\section{b. Aisyah 1 Dormitory}

Aisyah 1 Dormitory has a room size of 8 meters long and 7 meters wide inhabited by 18 students. has front (north) and rear (south) ventilation so that cross ventilation can occur in the room, while there are only 2 lamps. This room has 12 measuring points, consisting of measuring points near the opening and under the lamp. Measuring points that are close to openings towards the north or in front of the building, namely points A3, B3, C3 and D3, measuring points that are close to the openings towards the south or behind the building, namely points A1, B1, C1 and D1, while the measuring points are near with lamps namely points A2, B2, C2 and D2.

The results of measuring the light intensity of aisyah 1 dormitory for 3 days in 4 different times from $09.00-22.00$ GMT +8 as shown in Fig. 7 the graph of the measurement results of Aisyah's dormitory 1 figure. The highest light intensity is at point B2 in the morning, day, evening, or night, this is because point B2 is close to the lights, so the intensity is higher than the other points. While the lowest point is point D1 because the point is far from the lamp, even though it is close to the opening, there is a barrier in the form of a cupboard so that it gets less light from both lights and sunlight from outside the room.

The results of the above measurements are then made the average light intensity at Aisyah 1's dormitory for 3 days at 4 different times in the graph in Fig. 8.

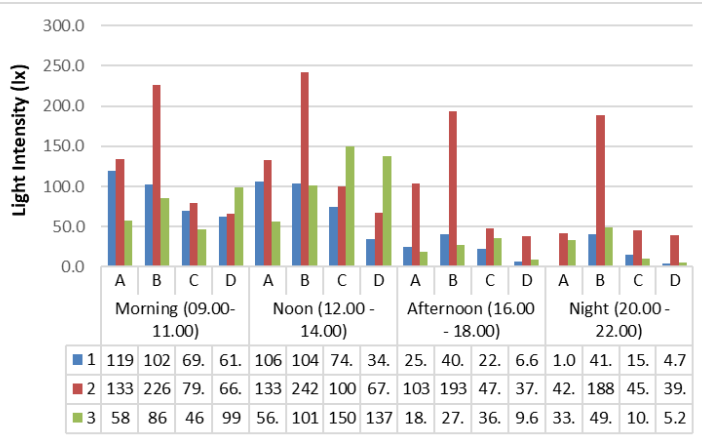

Figure 7. Measurement results of Aisyah 1 dormitory 


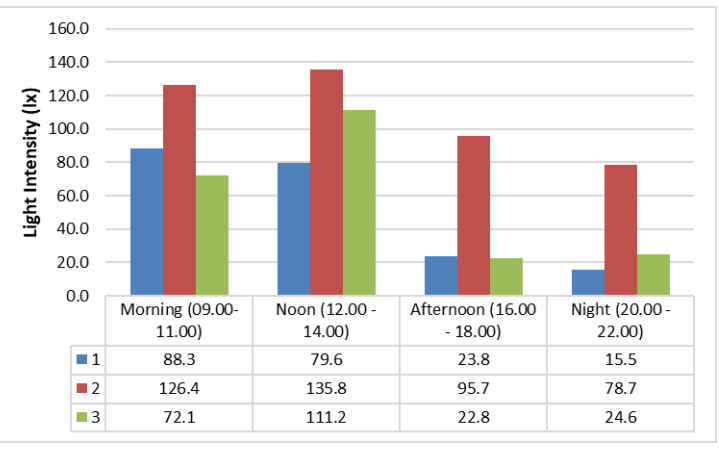

Figure 8. Average measurement results for aisyah 1 dormitory

Average of the highest measurement results during the day at point 2 (in the middle of the room) $135.8 \mathrm{~lx}$, but if it is compared to the Indonesian national standard of $250 \mathrm{~lx}$, it is concluded that the lighting of the Aisyah 1 dormitory for the study room does not meet the standard.

\section{c. Khadijah 2 Dormitory}

Khadijah 2 has a length of 13 meters and a width of 10.7 meters inhabited by 22 students. has 2 window openings (west direction) and rear ventilation (east direction), so cross ventilation cannot occurs in this room, while the number of lights there are only 2 lights. This room has 16 measuring points, consisting of measuring points near the openings and those under the lights. The measuring points that are close to the opening to the west are $\mathrm{A} 4$ and $\mathrm{D} 3$ points, while the measuring points that are close to the lights are B2, B3, C2 and C3.

The results of measuring the light intensity of Khadijah 2 Dormitory for 3 days in 4 different times from 09.00 22.00 GMT +8 as shown in Fig. 10 of the measurement results of the Khadijah 2 . The highest light intensity is at point B2 and B3 both in the morning, afternoon, evening, or night, this is because points B3 and B2 are close to lights, so their intensity is higher than other points. While the lowest point is point D3 because the point is far from lights and openings so that it gets less light from both lights and sunlight from outside the room.

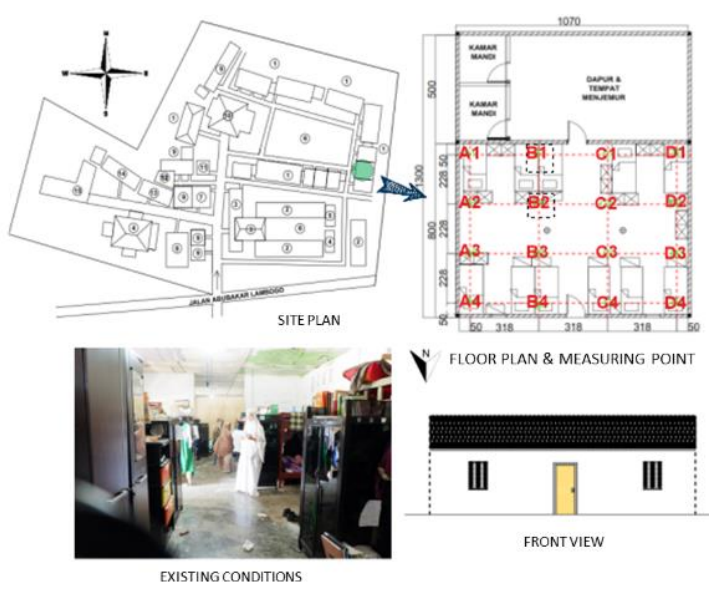

Figure 9. General overview of Khadijah 2 dormitory

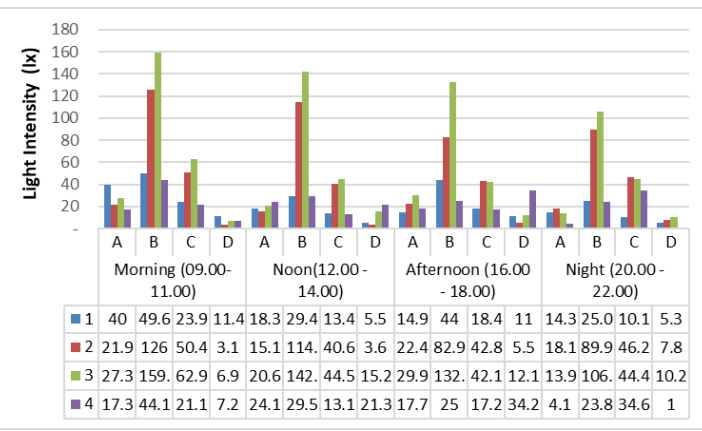

Figure 10. Measurement results of khadijah 2 dormitory

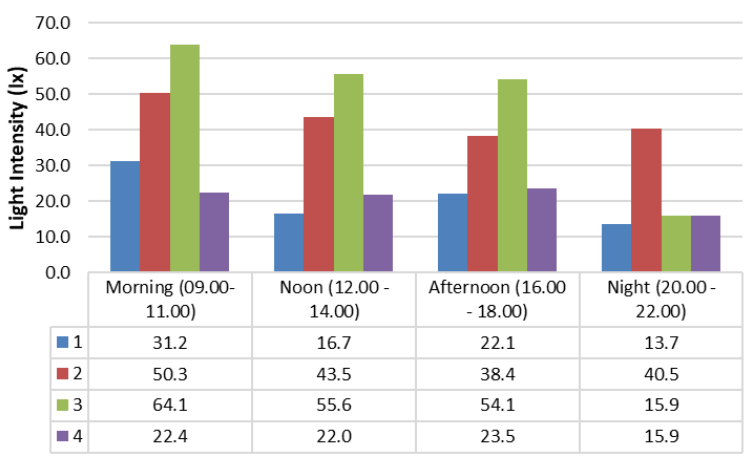

Figure 11. The average measurement of Khadijah 2 dormitory

The results of the above measurements then made the average light intensity at the khadijah 2 hostel for 3 days at 4 different times in the graph in Fig. 11. The average measurement result of the highest at point 3 (which is in the middle of the room) in the morning is $64.1 \mathrm{~lx}$, but when compared to the Indonesian national standard of $250 \mathrm{~lx}$, it is concluded that the lighting of the khadijah dormitory for the study room has not met the standards.

\section{d. Aminah 1 Dormitory}

Aminah dormitory has a room size of 6.7 meters long and 7.35 meters wide inhabited by 19 students, has window openings (west direction) and rear ventilation (east direction) in the kitchen, so cross ventilation cannot occurs in this room, while the number of lights are only 2 lights.

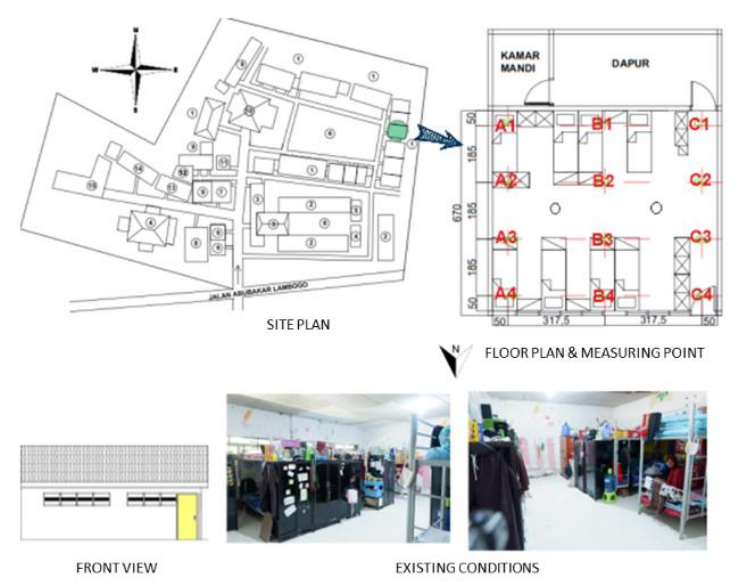

Figure 12. General overview of Aminah 1 dormitory 
This room has 12 measuring points, consisting of measuring points near the opening and under the lamp. The measuring points that are close to the opening to the west are points $\mathrm{A} 4, \mathrm{~B} 4$ and $\mathrm{C} 4$, while the measuring points that are close to the lights are points $\mathrm{B} 2$ and $\mathrm{C} 2$.

The results of measuring the light intensity of the aminah dormitory for 3 days in 4 different times from $09.00-22.00$ GMT +8 as shown in Fig. 13 on the graph of the measurement results of the aminah dormitory 1 figure.

The highest light intensity is at point B2 both in the morning and afternoon, evening, or night, this is because point $\mathrm{B} 2$ is close to the lights, so the intensity is higher than the other points. While the lowest point is point $\mathrm{C} 1$ because the point is far from lights and openings and there is a barrier in the form of a cupboard so that it gets less light from both lights and sunlight from outside the room.

The results of the above measurements then made the average light intensity at the Aminah 1 dormitory for 3 days at 4 different times in Fig. 14. The average measurement result of the highest at point 3 in the afternoon of $50.3 \mathrm{~lx}$, However, if it is compared with the Indonesian national standard, which is $250 \mathrm{~lx}$, it can be concluded that the lighting of the Aminah 1 dormitory for the study room has not met the standard.

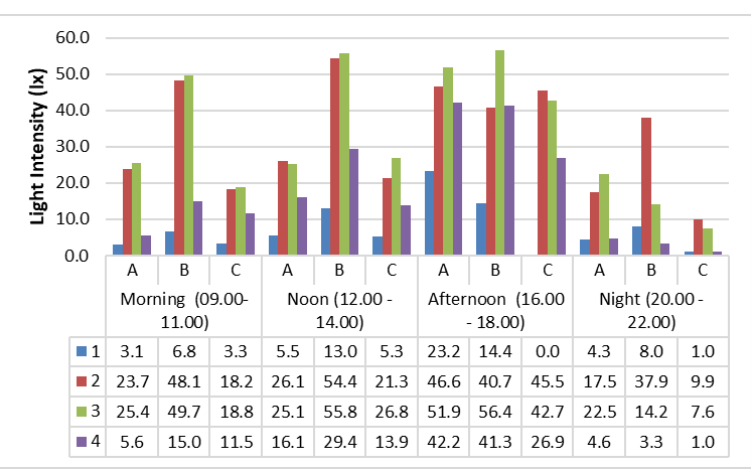

Figure 13. Measurement results for the Aminah 1 dormitory

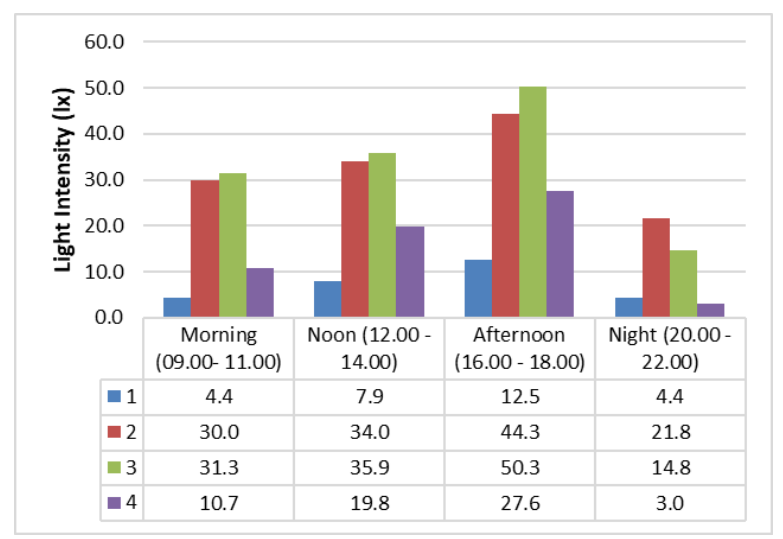

Figure 14. The average measurement results of the Aminah 1 dormitory

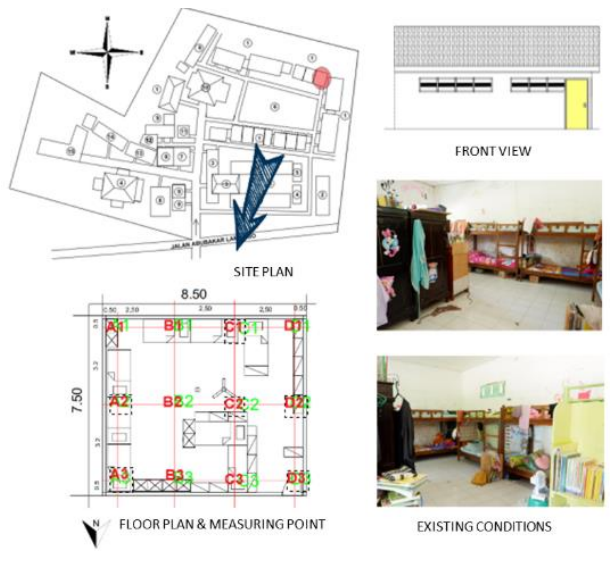

Figure 15. General overview of Hafsah 1 dormitory

\section{e. Hafsah 1 Dormitory}

Hafsah dormitory has a room size of 8.5 meters long and 7.5 meters wide inhabited by 20 students, has front (south) and rear (north) ventilation but is small so that cross ventilation can occur in the room this, while the number of lights there is only 1 lamp in the middle of the room. This room has 12 measuring points, consisting of measuring points near the opening and under the lamp. The measuring points that are close to the southern opening are points A3, $\mathrm{B} 3, \mathrm{C} 3$ and D3, the measuring points that are close to the southern vent are points $\mathrm{A} 1, \mathrm{~B} 1, \mathrm{C} 1$ and $\mathrm{D} 1$, while the measuring points that are close to the lights are points A2, $\mathrm{B} 2$, C2 and D2.

The results of measuring the light intensity of the hafsah 1 dormitory for 3 days in 4 different times from $09.00-22.00$ GMT +8 as shown in Fig. 16 of the measurement results of the Hafsah 1 dormitory figure. The highest light intensity at point $\mathrm{C} 2$ and $\mathrm{B} 2$ both in the morning, afternoon, evening, or night, this is because points $\mathrm{B} 2$ and $\mathrm{C} 2$ are close to lights, so their intensity is higher than other points. While the lowest points are points D1 and D3 because these points are far from the lights and close to the openings, but there are obstacles so that there is less light from both lights and sunlight from outside the room.

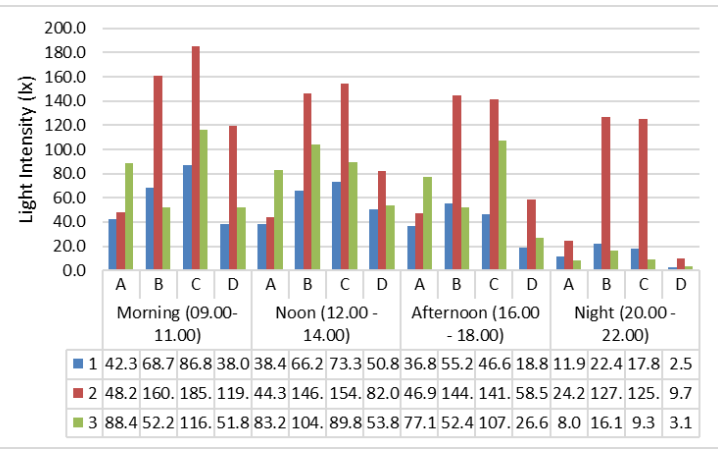

Figure 16. Measurement results for the Hafsah 1 dormitory 


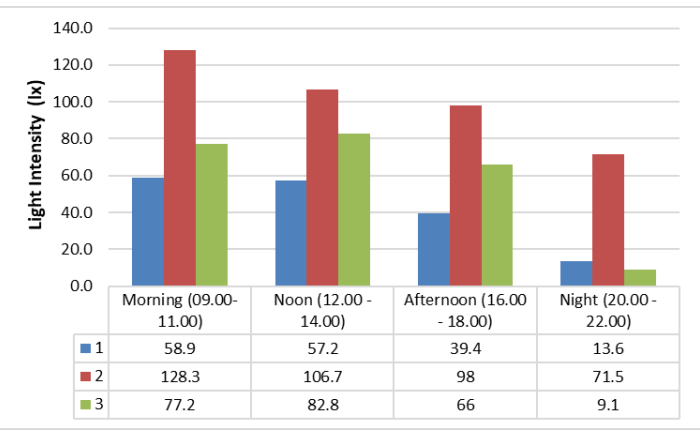

Figure 17. The average measurement results of the Hafsah 1 dormitory

The results of the above measurements then made the average light intensity at hafsah 1 dormitory for 3 days at 4 different times. Average measurement results at point 2 in the morning is $128.3 \mathrm{~lx}$ when compared to the Indonesian national standard, namely $250 \mathrm{~lx}$, it is concluded that the lighting of hafsah 1 dormitory for the study room has not met the standard.

\section{f. Maemunah 1 Dormitory}

Maemunah 1 dormitory has a room size of 8.5 meters long and 8.5 meters wide inhabited by 22 students, has 2 openings in front (south direction) and rear (north direction) but small so cross ventilation can occur in this room, while there are only 2 lights in the middle of the room. This room has 16 measuring points, consisting of measuring points near the openings and those under the lights. The measuring points that are close to the southern opening are points $\mathrm{C} 4$ and $\mathrm{B} 4$, measuring points that are close to the southern ventilation, namely points $\mathrm{A} 1, \mathrm{~B} 1, \mathrm{C} 1$ and $\mathrm{D} 1$, while the measuring points that are close to the lights are points B2, B3, C2 and C3 .

The results of measuring the light intensity of the maemunah 1 dormitory for 3 days in 4 different times from $09.00-22.00$ GMT +8 as shown in Fig. 19 of the measurement results of the maemunah 1 dormitory.
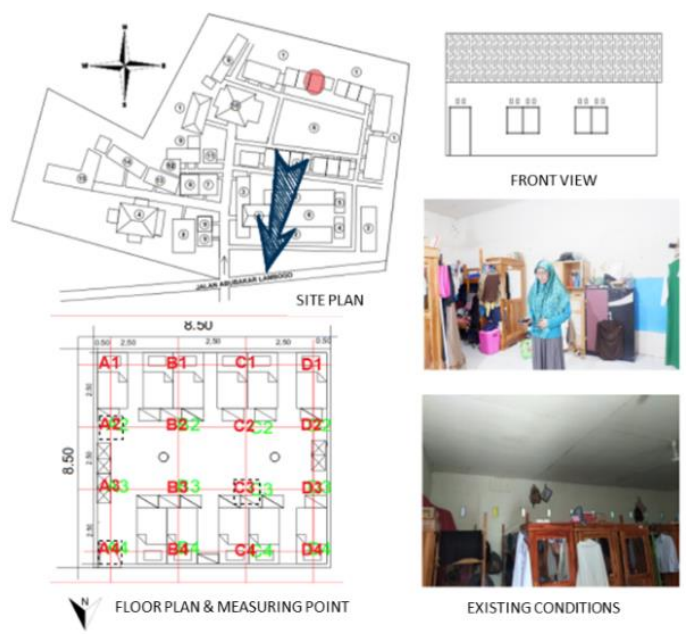

EXISTING CONDITIONS

Figure 18. General overview of Maemunahl dormitory

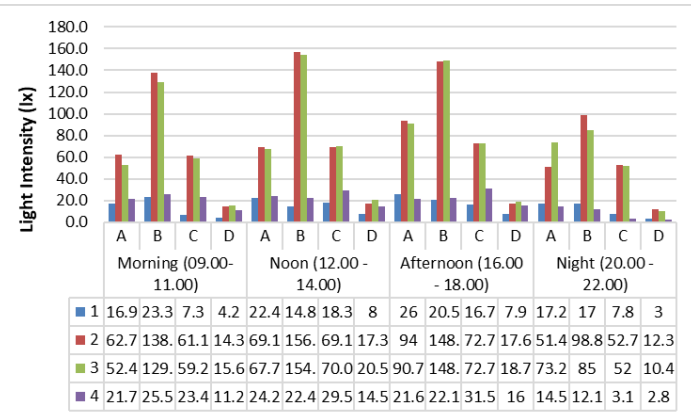

Figure 19. Measurement results of Maemunah 1 dormitory

The highest light intensity is at point B2 and B3 whether in the morning, afternoon, evening or night, this is because point B2 is close to the lights, so the intensity is higher than the other points. While the lowest point is point D1 because the point is far from lights and openings so that it gets less light from both lights and sunlight from outside the room.

The results of the above measurements then made the average light intensity at maemunah 1 dormitory for 3 days at 4 different times. The average measurement result at point 2 in the afternoon is $83.1 \mathrm{~lx}$ when compared to the Indonesian national standard, namely $250 \mathrm{~lx}$, it is concluded that the lighting of maemunah 1 dormitory for the study room has not met the standard.

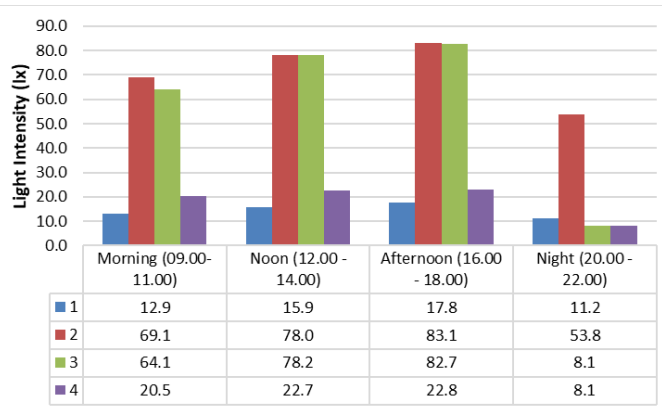

Figure 20. The average measurement results of the Maemunah 1 dormitory

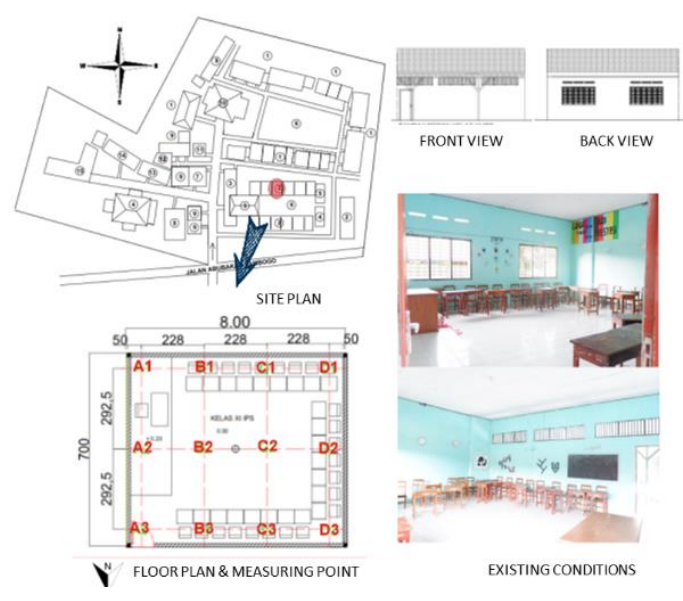

Figure 21. General overview of classroom XI IPS 


\section{g. Classroom XI IPS}

Classroom XI IPS with a south-north orientation has a room size of 8 meters long and 7 meters wide, has front (south) and rear (north direction) vents, so cross ventilation can occur in this room, while there is only 1 lamp in the middle of the room. This room has 12 measuring points, consisting of measuring points near the opening and those under the lamp. Measuring points near the south opening are points $\mathrm{A} 3, \mathrm{~B} 3, \mathrm{C} 3$ and D3, the measuring points that are close to the northern direction of the vent are $\mathrm{A} 1, \mathrm{~B} 1, \mathrm{C} 1$ and D1, while the measuring points that are close to the lights are points B2 and C2.

The results of measuring the light intensity of classroom, XI IPS for 3 days in 4 times which is different from $09.00-22.00$ GMT +8 as shown in Fig. 22 on the graph of measurement results for classroom XI IPS. The highest light intensity in classroom XI IPS is at point B1 both in the morning, afternoon, evening, and B2 at night, this is because B1 is directly near the window and point B2 is close to the light, so the intensity is higher than the other points. While the lowest points are points C2 and D3 in the morning, afternoon and evening, points A1 and D1 at night because these points are far from the lights so that they get less light from both lights and sunlight from outside the room.

The results of the above measurements then made the average light intensity in class XI IPS for 3 days at 4 different times.

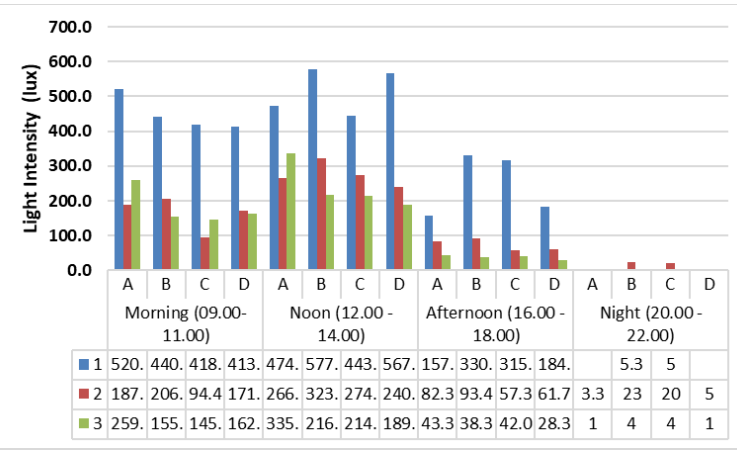

Figure 22. Measurement results of classroom XI IPS

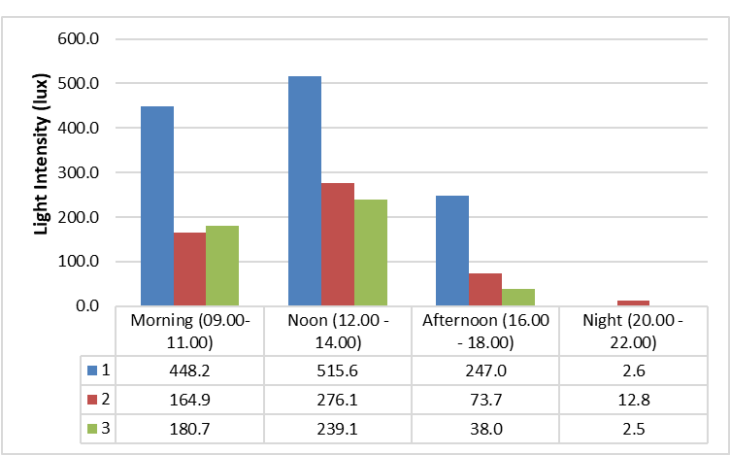

Figure 23. The average measurement results of classroom XI IPS
The average of the highest measurement results is at point 1 , which is on the north side of the wall where there are openings during the day of $515.6 \mathrm{~lx}$ when compared to the Indonesian national standard, which is $250 \mathrm{~lx}$, it is concluded that the lighting for class XI IPS during the day for the study room has met or exceeds the standard. It's just that at night it is impossible to use it for studying.

\section{h. Classroom VIII B}

Classroom VIII B with a south-north orientation has a room size of 8 meters long and 7 meters wide, has front (south) and rear (north) vents so that cross ventilation can occur in this room, while the number of lights there is only 1 lamp in the middle of the room. This room has 12 measuring points, consisting of measuring points near the opening and under the lamp. Measuring points that are close to the southern opening are points A3, B3, C3 and D3, measuring points that are close to the northern ventilation, namely points $\mathrm{A} 1, \mathrm{~B} 1, \mathrm{C} 1$ and $\mathrm{D} 1$, while the measuring points that are close to the lights are points B2 and $\mathrm{C} 2$.

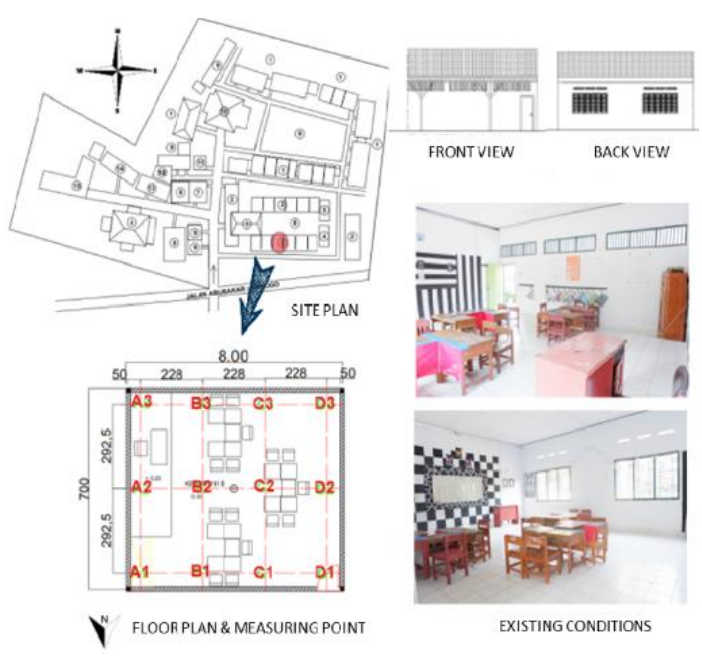

Figure 24. General overview of classroom VIII B

The results of measurement of classroom VIII B light intensity for 3 days in 4 different times from $09.00-22.00$ GMT +8 as shown in Fig. 25 of the classroom VIII B measurement graph. The highest light intensity is at point C3 both in the morning, noon, as well as the afternoon compared to other points. this is because point C3 is close to the opening and without obstructions, so that its intensity is higher than the other points. points A3 and B3 and those near the lower opening because they are blocked by the road surface behind the building which is higher than the opening, point D3 is closer to the wall so that the light intensity is lower. While the lowest point is point A1 because the point is far away from the opening so that it gets less light from sunlight from outside the room. 


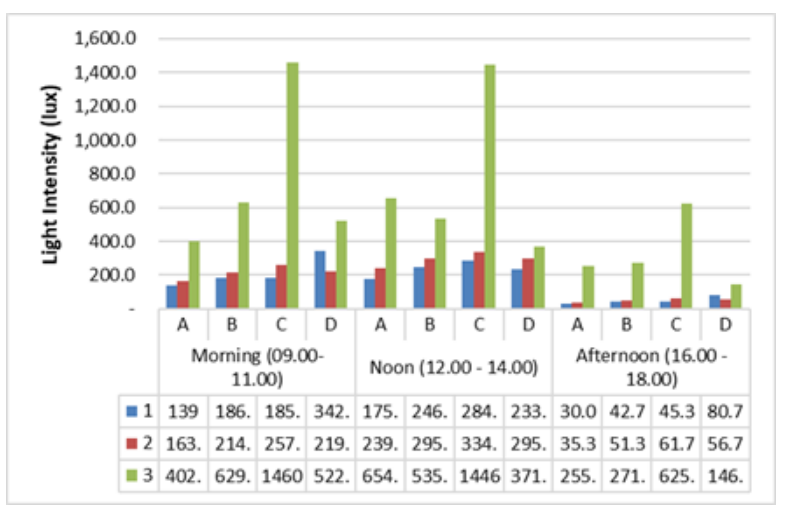

Figure 27. measurement results for clasrooms VIII B

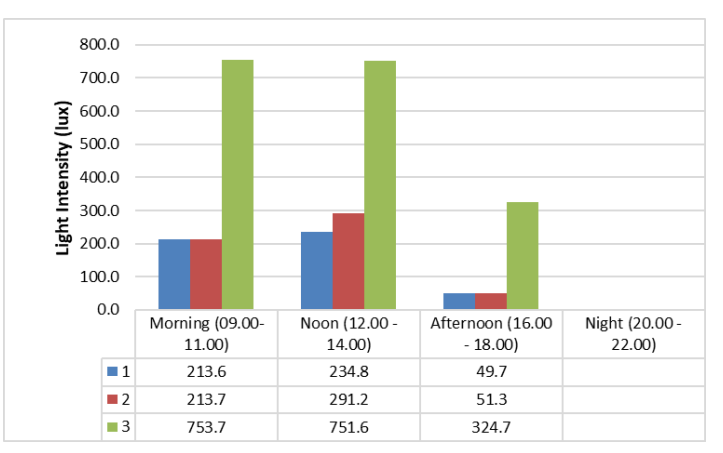

Figure 28. Average measurement results for classroom VIII B

The results of the above measurements then made the average light intensity in class VIII B for 3 days in 4 different times. The average of the highest measurement results at point 3 in the morning is $753.7 \mathrm{~lx}$, during the day is $751.6 \mathrm{~lx}$ and in the afternoon is $324.7 \mathrm{~lx}$ when compared to the Indonesian national standard, which is $250 \mathrm{~lx}$, it can be concluded that classroom VIII B lighting in the morning, afternoon and evening for the study room has met or exceeds the standard so that it allows glare, especially in areas close to openings. It's just that at night it can't be used for studying.

\subsection{Artificial lighting design recommendations}

After collecting data with measurements using a Lux Meter it is concluded that the lighting of the study room in the dormitory does not meet the standards used for learning in terms of lighting both during the day and at night, while the classroom as a place of study used during the day has met the standards lighting the study room, but at night the lighting in the classroom has not met the standard. Therefore, the researchers made recommendations for classrooms at night and dormitories that are in accordance with the lighting standards for the study room so that students can study in class at night and in dormitories.

\section{a. Islamic Boarding School Of DDI Lil Banat Classroom Lighting Design at night}

Classroom lighting design recommendations as shown in the picture above use an even lighting system with 4 lamps, the type of lamp used is the PHILIPS RC341B PSU

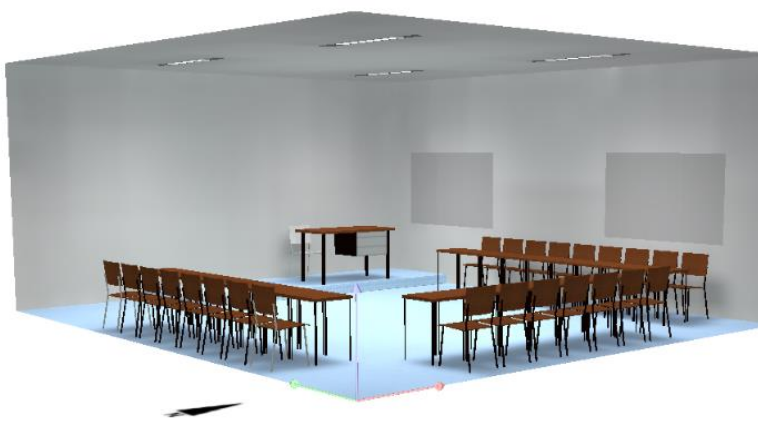

Figure 25. Recommended classroom lighting

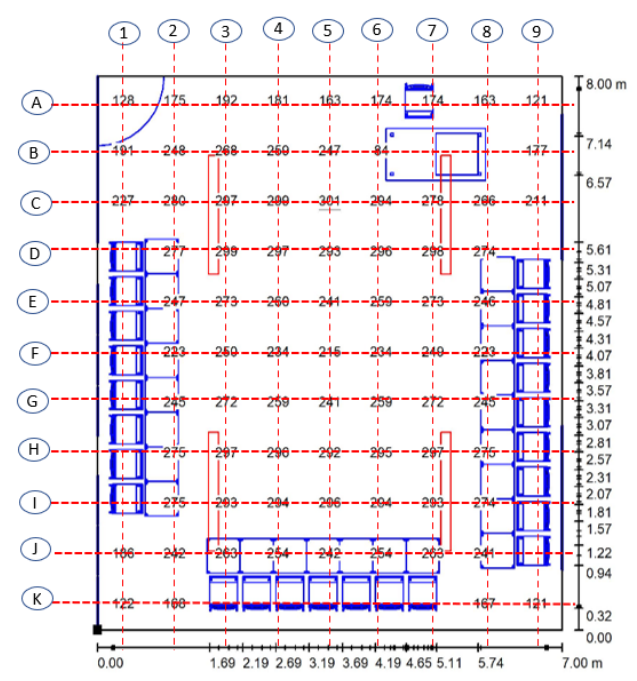

Figure 26. Simulation result of classroom

W15L180 1 xLED42S / $8304200 \mathrm{~lm}$ and 31 watts. The distance between the lights is 3.5 meters and 2.28 meters. From Fig. 28 it can be seen that the workplane area of $76 \mathrm{~cm}$ from the floor surface has a value of approximately $250 \mathrm{~lx}$. The highest light intensity value is $301 \mathrm{~lx}$, while the lowest light intensity is $39 \mathrm{~lx}$ with an average light intensity of $226 \mathrm{~lx}$. The average light intensity on the table or study area is $255 \mathrm{~lx}$, while the standard of lighting for the study room is $250 \mathrm{~lx}$, so the classroom meets the standard and can be used by students to study at night.

\section{b. Lighting Design of Islamic Boarding School of DDI Lil Banat Dormitory at night}

Recommendations for placing lights in order to meet the light intensity in the dormitory according to the Indonesian National Standard and for user convenience there are two options for 2 different dorm plans. The first is for the dormitory plan where the bed placement is linear, so that the study area is in the middle of the room which is more like a corridor. The second is for dormitory plans where the bed is laid out in a U-shape so that the study area is in the middle and wider, according to the layout in the field. 


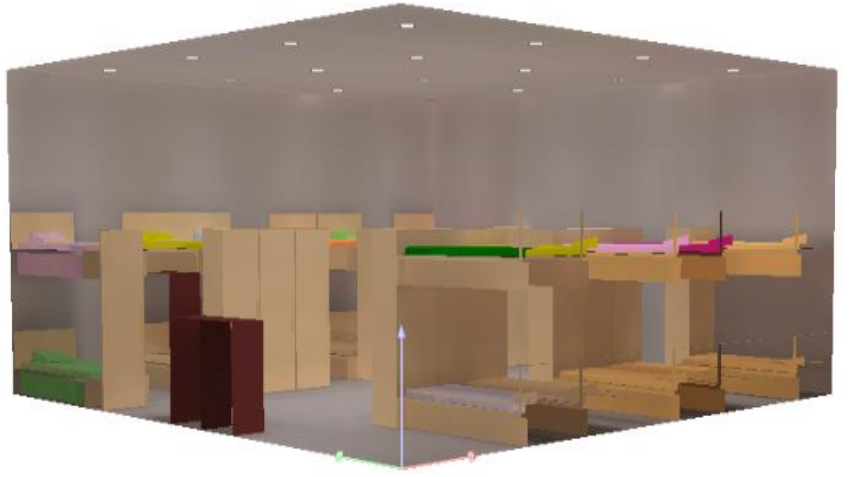

Figure 29. Dormitory lighting recommendations at night

The first recommendation is a linear plan with the simulation results such as Fig. 29. Recommendations as shown in Fig. 29 use an even lighting system with 16 lamps, the type of lamp used is PHILIPS DN570B PSE-E 1xLED12S / 930 F SG-FRC $900 \mathrm{~lm}$ and 11.6 Watt. The distance between the lights is 2.1 meters.

The simulation results of the dormitory at the Islamic boarding school of DDI Lil Banat showed unfavorable results, therefore a recommendation was made for good lighting design to be used for all activities in the dormitory, especially studying and sleeping. Design recommendations that have been made based on SNI standards for lighting while studying are $250 \mathrm{~lx}$ and 120-250 $\mathrm{lx}$ during sleep. Below are the results of the simulation of the dormitory lighting system recommendations.

From Fig. 30 it can be seen that the area that is often used for learning, namely in the middle of the workplane room $80 \mathrm{~cm}$ from the floor surface, has a value of approximately $250 \mathrm{~lx}$. The highest light intensity value is $256 \mathrm{~lx}$, while the lowest light intensity is $51 \mathrm{~lx}$ with an average light intensity of $170 \mathrm{~lx}$. The average light intensity in the study area is 244.5 lx, while the standard of lighting for the study room is $250 \mathrm{~lx}$, with a difference of $5.5 \mathrm{~lx}$, the dormitory can be used by students to study at night. While the area for sleep from the simulation results, the value of the light intensity ranges from $120-250 \mathrm{~lx}$ so it is good to use for sleeping.

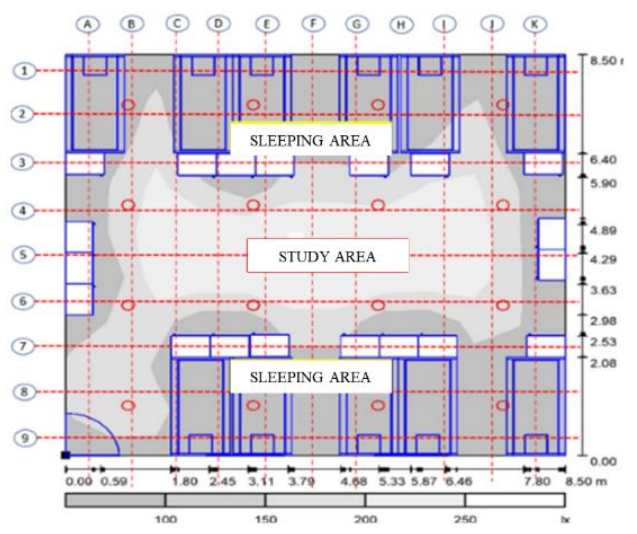

Figure 30. The distribution of light from the simulation results of dormitory lighting recommendations.

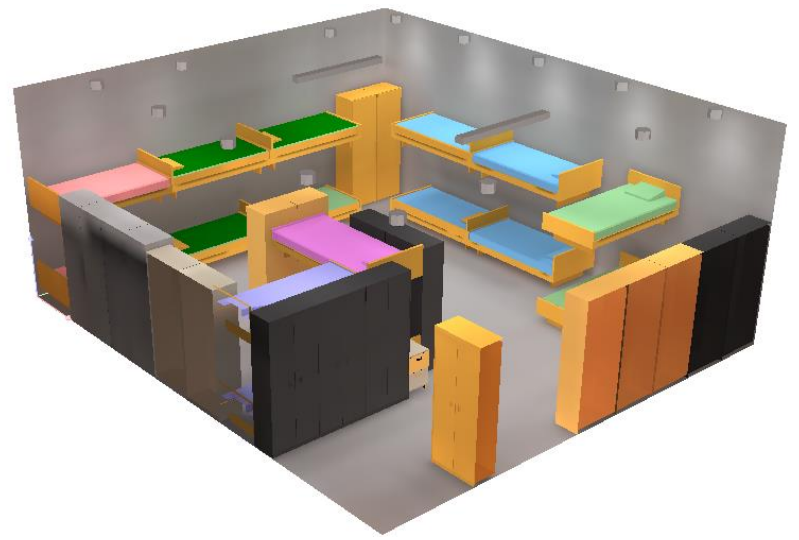

Figure 31. Alternative dormitory lighting recommendations 1

The second recommendation, namely a U-shaped dormitory plan. The simulation is carried out as many as 2 alternatives, the first alternative is a lamp for sleeping, the light intensity is as standard, ranging from 120-250 lx and the second alternative is the lamp used during study time and extinguished when it is bedtime.

The results of the first alternative simulation for the $\mathrm{U}$ layout type are as shown in Fig. 31. Dormitory lighting design recommendations for alternative U-type layouts are shown in Fig. 31 using a combined evenly and localized lighting system with 14 light points located in Fig. 31. edge close to the wall, the type of lamp used is PHILIPS DN571B PSE-E 1xLED12S / 930 F SG-FRC $1050 \mathrm{~lm}$ and 11.8 Watt. The distance between the lights is 2.1 meters which is turned on when you want to sleep.

The simulation results of the dormitory at the Islamic boarding school of DDI Lil Banat show unfavorable results for studying because it is dark and glare for sleeping, therefore a recommendation is made for lighting design that is good for sleeping. Design recommendations that have been made based on SNI standards for lighting during sleep are $120-2501 \mathrm{~lx}$. Below are the results of the simulation of alternative dormitory lighting system recommendations 1 .

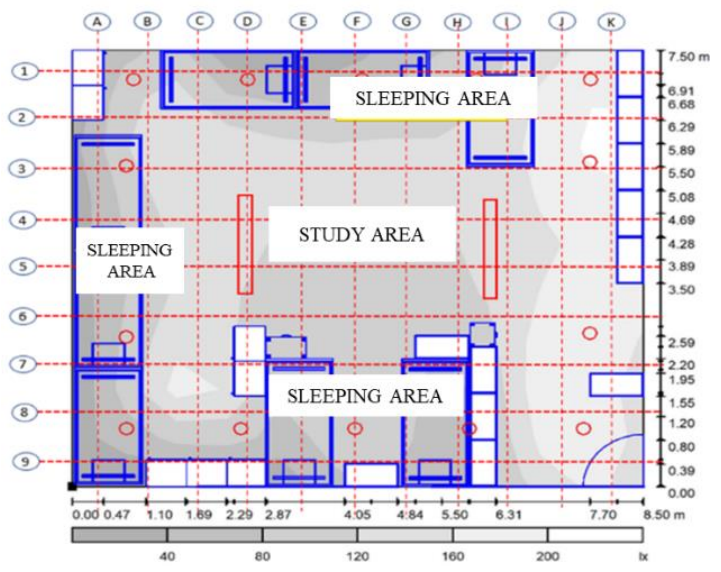

Figure 32. The light distribution from the simulation results. Alternative Dormitory Lighting Recommendations 1 


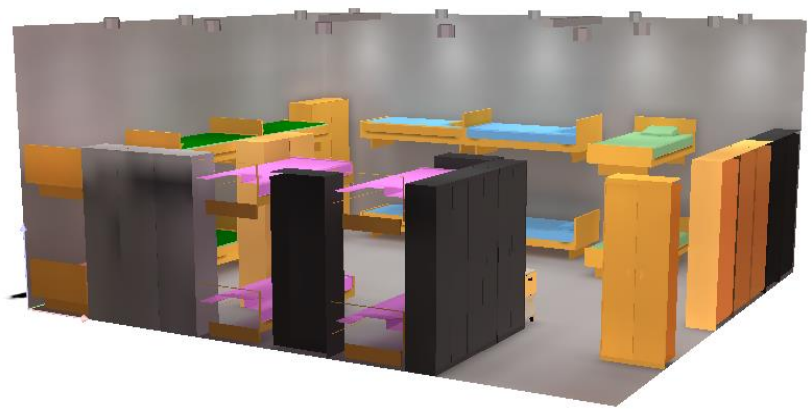

Figure 33. Results of recommendations 2 for alternative dormitory lighting

From Fig. 32 it can be seen that the bed area, which is the edge of the room, has a value of approximately $200 \mathrm{~lx}$ or ranges from $40-200 \mathrm{~lx}$, meaning that the room can be used for sleeping because it has reached the bedroom lighting standard. ie 120-250 lx.

The simulation results of the two alternative lights are used for learning, as shown in Fig. 33. Recommendations for dormitory lighting design for alternative $U$ type layout 2 as shown in the picture above using a combined lighting system having 2 light points in the middle of the room, the type of lamp used is PHILIPS RC341B PSU W15L180 1 xLED42S / $8304200 \mathrm{~lm}$ and 31 watts. The distance between lamps is 3.65 meters distance between lamps and 2.5 meters distance from the walls.

The simulation results of the dormitory at the Islamic boarding school of DDI Lil Banat showed unfavorable results for studying because it was dark and glare for sleeping, therefore recommendations for lighting design were made that were good for learning. Design recommendations that have been made based on SNI standards for lighting when studying are 250 lx. Figure 34 are the results of the simulation of an alternative dormitory lighting system recommendation.

Figure 34 shows that the study area, which is in the middle of the room, has a light intensity value between 180 - 290 lx. The highest light intensity value is 290 lx and the lowest light intensity is $14 \mathrm{~lx}$ with an average light intensity

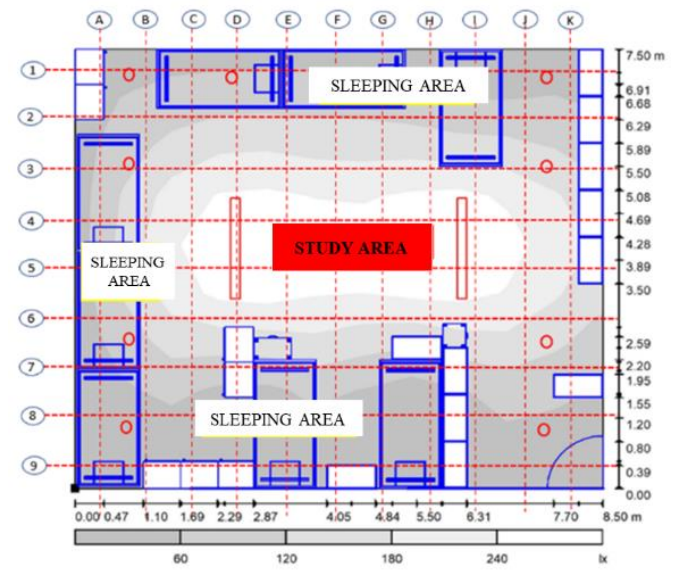

Figure 34. The light distribution simulation results for alternative dormitory lighting recommendations 2 When the study lights are turned on and the sleep lights are turned off of $130 \mathrm{~lx}$. The standard of lighting for the study room is $250 \mathrm{~lx}$, so the dormitory with lighting like in session 2 can be used by students to study.

\section{Conclusions and Suggestion}

\subsection{Conclusions}

The results of measuring light intensity in the study room at the Islamic boarding school of DDI Lil Banat show that none of the light intensity in the dormitory meets the Indonesian National Standard for study rooms both at night and during the day. During the day the classrooms meet Indonesian National Standards but not at night. Even though students as room users feel comfortable with the light intensity conditions in the study room and can study according to these conditions, the students still feel some complaints in the form of sore eyes, eye tension and difficulty focusing. So, the researchers made recommendations for study room designs that could make students more comfortable studying in dormitories and classes so that they could reduce complaints while studying. Lighting design recommendations are made in several alternatives by increasing the number of lamps and changing the lamp type using Dialux simulation. The simulation results of the study room lighting design recommendations have met the standards for use so that they can be applied to dormitories and classes at the Islamic boarding school of DDI Lil Banat Parepare.

\subsection{Suggestions}

Based on the above conclusions, the authors provide suggestions to further researchers who wish to conduct research with a similar theme in order to provide information about the quality of lighting in dormitories according to SNI and its effect on activities in dormitories other than studying and sleeping. Suggestions for practitioners with this research are expected to be a reference in dormitory design and consideration in terms of dormitory lighting design so that it can support students' learning activities.

\section{References}

[1] Manurung, Natural Lighting in Architecture. Yogyakarta: ANDI, 2012. [in Bahasa]

[2] N. Jamala and Rahim, Visual Comfort Theory and Applications. Makassar: Badan Penerbit UNM, 2017. [in Bahasa]

[3] N. Jamala, N. Soewarno, J. A. Suryabrata, and A. Kusumawanto, "Visual Comfort of Office Workspace," Forum Tek., vol. 35, no. 1, 2013. [in Bahasa]

[4] H. Indrani and I. P. Santosa, Hospital Lighting Design Upscale Hospital. Darmo and St. Vincentius A. Paulo Surabaya. Surabaya, 2009. [in Bahasa]

[5] Mahmuddin, "Learn and Share," 2010. [Online]. Available: www.mahmuddin.wordpress.com. [Accessed: 04-Sep-2017]. [in Bahasa]

[6] M. Soeripto, "Higiene Industri," Universitas Indonesia, 2008. [in Bahasa]

[7] E. Widowati, "Effect of Local Lighting Intensity," J. Kesehat. Masy. Uns. Kesmas, vol. 5, no. 1, 2010. [in Bahasa]

[8] Kwong and Ali, "A Review of Energy Efficiency Potentials in Tropicsl Buildings-Perspective of Enclosed Common Areas," Renew. Sustain. Energi Rev., 2011 
[9] R. Prihatmanti and M. Y. Susan, "Lighting Performance in Classrooms in Historic Buildings," Aksen, vol. 46, 2016. [in Bahasa]

[10] S. Samani, "The Impact of Indoor Lighting on Students' Learning Performance in Learning Environments," Int. J. Bus. Soc. Sci., vol. 3, no. 24, 2012

[11] Nurul, "Study of Natural Lighting in Central Library Building of UNHAS," J. Enj., 2001. [in Bahasa]

[12] U. Awak, "Conducive Study Room Physical Conditions," 2015. [Online]. Available: https://www.matrapendidikan.com/2015/04/kondisi-ruangbelajarkondusif.html\%0A. [Accessed: 01-Apr-2015]. [in Bahasa]

[13] W. Udin S, Teaching and Learning Strategy. Jakarta, 2003. [in Bahasa]
[14] Z. Dhofier, The Tradition of Islamic Boarding Schools Studying Kyai's View of Life and His Vision on Indonesia's Future. Jakarta Barat: LP3ES, 2011. [in Bahasa]

[15] H. F. Zarkasyi, Liberalization of Islamic Thought (Joint Movement of Missionaries, Orientalists, and Colonialists). Ponorogo: CIOS, 2008. [in Bahasa]

[16] Pareparekota, "Parepare City Statistics," 2016. [in Bahasa]

[17] Janah, "DDI Lil Banat Islamic Boarding School Parepare," 2013. [Online].

Available: https://pareparekota.go.id/index.php/profil/geografis/. [Accessed 25-Jul-2021]. [in Bahasa] 